\title{
High-Performance Liquid Chromatographic Analysis of ${ }^{32} \mathrm{P}$-Postlabeled DNA-Aromatic Carcinogen Adducts ${ }^{1}$
}

\author{
Gerald N. LEVY AND WENDELl W. WeBER \\ Department of Pharmacology, University of Michigan Medical School, Ann Arbor, Michigan 48109
}

Received February 29, 1988

\begin{abstract}
The technique of ${ }^{32} \mathrm{P}$ postlabeling of DNA-carcinogen adducts is a useful and extremely sensitive method of detecting and quantitating DNA damage by carcinogens. We have adapted the ${ }^{32} \mathrm{P}$ method to analysis by high-pressure liquid chromatography, making the procedure more rapid and convenient than when thin-layer chromatography is used. Following DNA isolation and hydrolysis, nucleotide-carcinogen adducts are enhanced relative to normal nucleotides by solvent extraction and then labeled with high-specific-activity $\left[\gamma-{ }^{32} \mathrm{P}\right] \mathrm{ATP}$. The resulting ${ }^{32} \mathrm{P}$. postlabeled nucleotides are resolved by reverse-phase ion-pair HPLC. After as little as $3 \mathrm{~h}$ of exposure to carcinogens, DNA adducts can be demonstrated from $1 \mu \mathrm{g}$ or less of mouse hepatic DNA. Acetylated and nonacetylated adducts can be resolved from hepatic DNA of mice treated with 2-aminofluorene. Differences in DNA damage as measured by adduct formation were demonstrated between "rapid" and "slow" acetylator mouse strains. Rapid-acetylator C57BL/6J mice had three times the amount of hepatic DNA adducts as slow-acetylator A/J mice $3 \mathrm{~h}$ after a $60 \mathrm{mg} / \mathrm{kg}$ dose of 2-aminofluorene. 4-Aminobiphenyl and 2-naphthylamine each showed an adduct peak with retention time similar to that of the nonacetylated 2-aminofluorene adduct, while benzidine gave a major adduct that eluted somewhat earlier as would be expected for an acetylated adduct. The alkenylbenzenes, safrole and methyleugenol, also formed DNA adducts detectable by this method. DNA prepared from skin of mice painted with benzo[a]pyrene also contained carcinogen-DNA adducts detectable and resolvable by HPLC arralysis following ${ }^{32} \mathrm{P}$ postlabeling. The combination of HPLC with ${ }^{32} \mathrm{P}$ postlabeling appears to be a useful technique for the rapid detection and quantitation of DNA damage caused by several classes of aromatic carcinogens. ๑1 1988 Academic Press, Inc.

KEY WORDS: HPLC; nucleic acids; ${ }^{32} \mathrm{P}$ postlabeling; DNA adducts; 2-aminofluorene; $N$-acetylation.
\end{abstract}

The formation of a covalent adduct between a carcinogen/mutagen and a DNA nucleotide is generally considered a crucial step in a common mechanism of carcinogenesis/ mutagenesis. Detection and quantitation of such a complex require extremely sensitive methods as the level of adducted nucleotides may be only 1 in $10^{6}$ to 1 in $10^{9}$ or less normal

\footnotetext{
${ }^{1}$ This research was supported by USPHS Grants CA39018 and GM-27028. Brief preliminary accounts of this work have been presented at the 26th Annual Meeting of the Society of Toxicology, Washington, DC, February 1987, and the Third International Conference on Carcinogenic and Mutagenic $N$-Substituted Aryl Compounds, Dearborn, MI, April 1987.
}

nucleotides. The introduction of ${ }^{32} \mathrm{P}$ postlabeling of adducted nucleotides by Randerath et al. (1) and Gupta et al. (2) is proving to be a useful addition to the methods of detecting adducts. The advantages of ${ }^{32} \mathrm{P}$ postlabeling compared with other sensitive methods include the wide applicability of the method to adducts formed from many aromatic and nonaromatic carcinogens (3), the elimination of radiolabeled carcinogens which may be expensive, in need of custom synthesis, or of unacceptably low specific activity, and the absence of the need to produce antibodies as required in immunological methods.

The clear advantage of ${ }^{32} \mathrm{P}$ postlabeling as a screening method for carcinogens is some- 
what mitigated by the need to separate the adducts by multiple-solvent thin-layer chromatography (TLC) and detect the results by autoradiography. Quantitation is then carried out by cutting out the radioactive areas or scraping the plates and scintillation counting. These procedures are time consuming and must be done with great care and precision to achieve reproducible results.

We have adapted the detection and quantitation aspects of ${ }^{32} \mathrm{P}$ postlabeling to HPLC. Postlabeled nucleotide adducts are separated from normal nucleotides, ATP, $P_{\mathrm{i}}$, and other components by reverse-phase ion-pair HPLC using a gradient of acetonitrile in phosphate buffer containing ion-pairing reagent. This method has been extremely reproducible, detects a variety of carcinogen-DNA adducts, and requires about $60 \mathrm{~min}$ from ${ }^{32} \mathrm{P}$ labeling to results. In experiments with radiolabeled carcinogen, it was found that the HPLC method is useful with nucleotide $3^{\prime}$-phosphates as well as with the nucleotide $3^{\prime}, 5^{\prime}$-diphosphates. The method we describe is useful not only in determining if the aromatic carcinogens have formed covalent DNA adducts, but also in partially resolving various adducts from one another and quantitating total adduct formation. We include data on the use of HPLC analysis of ${ }^{32} \mathrm{P}$-postlabeled DNA-2-aminofluorene adducts from two inbred mouse strains which demonstrate differences in their ability to $\mathrm{N}$-acetylate aromatic amines.

\section{MATERIALS AND METHODS}

Animals and chemicals. Mice (C57BL/6J and $A / J$ ) were purchased from Jackson Laboratories, Bar Harbor, Maine. Polynucleotide kinase, 3'-phosphatase free, was from Boehringer-Mannheim Biochemicals, Indianapolis, Indiana. Tetrabutylammonium phosphate, tetramethylammonium chloride, 4$\mathrm{ABP},{ }^{2}$ safrole, and methyleugenol were from

\footnotetext{
${ }^{2}$ Abbreviations used: 2-AF, 2-aminofluorene; 2NA, 2-naphthylamine; 4-ABP, 4-aminobiphenyl; AAF,
}

Aldrich Chemical Company, Milwaukee, Wisconsin. 3',5'-Diphosphates of deoxynucleotides were from Pharmacia P-L Biochemicals, Piscataway, New Jersey. $N$-Acetoxy-AAF was from the NCI Chemical Carcinogen Repository, $N$-acetoxy-2-acetylamino-[ring-G- $\left.{ }^{3} \mathrm{H}\right]$ fluorene was from Chemsyn Science Labs, Lenexa, Kansas. dG-C8$\Lambda \mathrm{F}-3^{\prime}$-phosphate was a gift from $\mathrm{Dr}$. Charles King and Tom Reid, Michigan Cancer Foundation, Detroit, Michigan. $\left[\gamma-{ }^{32}\right.$ P]ATP was from Amersham, Arlington Heights, Illinois. Acetonitrile was Fisher HPLC grade. Protease $\mathrm{K}$, spleen phosphodiesterase II, micrococcal nuclease, nuclease P1, RNase's, apyrase, 2-AF, 2-NA, benzidine, and ATP were from Sigma Chemical Company, St. Louis, Missouri. Benzo[ $[a]$ pyrene-adducted mouse skin DNA was a gift from Dr. David Springer, Battelle Laboratories, Richland, Washington.

Isolation of DNA. Hepatic DNA was prepared by homogenization of fresh or frozen liver in $50 \mathrm{~mm}$ Tris, $25 \mathrm{~mm} \mathrm{KCl}, 5 \mathrm{~mm}$ $\mathrm{MgCl}_{2}, 250 \mathrm{~mm}$ sucrose, $\mathrm{pH}$ 7.5. The homogenate was added to an equal volume of $1 \mathrm{M}$ $\mathrm{NaCl}, 0.1 \mathrm{M}$ EDTA, $2 \%$ SDS, pH 8, at $60^{\circ} \mathrm{C}$ and maintained at this temperature for 15 min. The lysate was cooled to $37^{\circ} \mathrm{C}$ and incubated with $0.5 \mathrm{mg} / \mathrm{ml}$ proteinase $\mathrm{K}$ for 60 $\min$. The DNA was extracted sequentially with $1 \mathrm{vol}$ phenol, $1 \mathrm{vol}$ phenol/chloroform/ isoamyl alcohol (25:24:1), and 1 vol chloroform/isoamyl alcohol (24:1). After ethanol precipitation, the DNA was redissolved in 10 mM Tris, 1 mM EDTA (pH 7.5). DNA was further treated with RNase $\mathrm{A}(100 \mu \mathrm{g} / \mathrm{ml})$ and RNase $\mathrm{T} 1(50 \mathrm{U} / \mathrm{ml})$ at $37^{\circ} \mathrm{C}$ for $30 \mathrm{~min}$, followed by addition of SDS to $0.5 \%$ and 0.5 $\mathrm{mg} / \mathrm{ml}$ proteinase $\mathrm{K}$ and incubation for a fur-

2-acetylaminofluorene; dG, deoxyguanosine; dG-C8AAF, $N$-acetyl- $N$-(deoxyguanosin-8-yl)-2-aminofluorene or its 3',5'-diphosphate; dG-C8-ABP, $N$-(deoxyguanosin-8-yl)-4-aminobiphenyl; dG-C8-AF, $N$-(deoxyguanosin-8-yl)-2-aminofluorene or its $3^{\prime}, 5^{\prime}$-diphosphate; $N$-acetoxy-AAF and $N$ - $\left[{ }^{3} \mathrm{H}\right]$ acetoxy-AAF, $N$-acetoxy-2acetylaminofluorene and ring-labeled $N-\left[{ }^{3} \mathrm{H}\right]$ acetoxy-2acetylaminofluorene; pdGp, deoxyguanosine $3^{\prime}, 5^{\prime}$-diphosphate; TBAP, tetrabutylammonium phosphate. 
TABLE 1

CARCinogens Tested

\begin{tabular}{lclc}
\hline Compound & $\begin{array}{c}\text { Dose } \\
(\mu \mathrm{mol} / \mathrm{kg})\end{array}$ & Solvent & $\begin{array}{c}\text { Number } \\
\text { of mice } \\
\text { examined }\end{array}$ \\
\hline 2-AF & 330 & DMSO $^{a}$ & 16 \\
4-ABP & 860 & Tricap $^{b}$ & 3 \\
2-NA & 350 & DMSO & 2 \\
Benzidine & 315 & DMSO & 2 \\
Safrole & 600 & Tricap & 2 \\
Methyleugenol & 2000 & Tricap & 2 \\
\hline
\end{tabular}

${ }^{a}$ Dimethyl sulfoxide.

${ }^{b}$ Tricaprylin.

ther $30 \mathrm{~min}$. This was followed by two extractions with chloroform/isoamyl alcohol (24: 1). After precipitation with ethanol, the DNA was dissolved in succinate buffer $(20 \mathrm{mM} \mathrm{Na}$ succinate, $10 \mathrm{mM} \mathrm{CaCl}_{2}, \mathrm{pH}$ 6). Quantitation of DNA was by absorbance at $260 \mathrm{~nm}$.

In vitro modification of DNA and preparation of adduct standards. Hepatic DNA was treated with $N$-acetoxy-AAF (2 mM) in 10

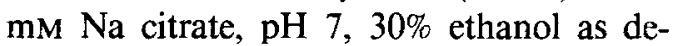
scribed by Gupta et al. (2). Repeated extraction with diethyl ether was used to remove unbound carcinogen. The modified DNA was precipitated with ethanol.

A similar procedure was used with $50 \mu \mathrm{l}$ of $N$ - $\left[{ }^{3} \mathrm{H}\right]$ acetoxy-AAF $(938 \mathrm{mCi} / \mathrm{mmol}, 1.45$ $\mathrm{mCi} / \mathrm{ml})$ and $142 \mu \mathrm{g}$ DNA.

The acetylaminofluorene adduct of deoxyguanosine 3 ',5'-diphosphate was prepared as above using $15 \mathrm{~mm}$ pdGp and $10 \mathrm{mM} N$-acetoxy-AAF in $200 \mu 1$ of $5 \mathrm{~mm} \mathrm{Na}$ acetate, $\mathrm{pH}$ $4.8,50 \%$ ethanol as described by Gupta et al. (2).

The acetylated aminofluorene adduct of deoxyguanosine 3 '-phosphate was similarly prepared.

In vivo modification of $D N A$. Mouse hepatic DNA was prepared from individual C57BL/6J inbred mice injected ip with carcinogens in the doses and solvents shown in Table 1. The volume injected was $100-150$ $\mu \mathrm{l}$. The exposure time was $3 \mathrm{~h}$. For each sub- stance tested a control injected with solvent only was used.

To study the effect of differing $N$-acetyltransferase activity on adduct formation, inbred $\mathrm{C} 57 \mathrm{BL} / 6 \mathrm{~J}$ (B6) and $\mathrm{A} / \mathrm{J}$ (A) mice were injected ip with $2-A F$ in DMSO $(60 \mathrm{mg} / \mathrm{kg})$. At $3 \mathrm{~h}$, the mice were sacrificed and hepatic DNA was prepared as described. In each experiment a littermate was dosed with DMSO only and used as a control for adduct determination.

Hydrolysis of DNA. Hydrolysis was a modification of the method of Gupta et al. (2). In most experiments 2-5 $\mu$ g DNA was digested in succinate buffer ( $\mathrm{pH} \mathrm{6}$ ) containing $10 \mathrm{mM}$ $\mathrm{CaCl}_{2}$ with $0.05 \mathrm{U}$ spleen phosphodiesterase II and $2.25 \mathrm{U}$ micrococcal nuclease in $20 \mu \mathrm{l}$ total volume for $3 \mathrm{~h}$ at $37^{\circ} \mathrm{C}$.

Enrichment of adducts. A modification of the butanol extraction procedure of Gupta (4) was used. To $20 \mu \mathrm{l}$ DNA hydrolysis reaction were added $25 \mu \mathrm{l} 100 \mathrm{mM}$ ammonium formate $\mathrm{pH} 3,15 \mu \mathrm{l} 50 \mathrm{mM}$ tetrabutylammonium chloride, and $10 \mu \mathrm{l}$ water. This was extracted twice with $70 \mu 11$-butanol (water saturated) and the combined extracts were back-extracted with $125 \mu \mathrm{l}$ water (butanol saturated). After addition of $3 \mu 1$ of $200 \mathrm{~mm}$ Tris, $\mathrm{pH} 9.5$, to the final butanol extract, the extract was dried using a Speed-Vac.

${ }^{32}$ P labeling of nucleotides. The dried preparation of butanol-extracted nucleotides was redissolved in $15 \mu \mathrm{l}$ water and labeled with 5 $\mu l$ of a labeling mix. The mix was prepared so that each $5 \mu$ l contained $2.5 \mu \mathrm{l} 10 \times$ buffer $(0.1$ $\mathrm{M}$ Bicine, $0.1 \mathrm{M} \mathrm{MgCl}_{2}, 0.1 \mathrm{M}$ dithiothreitol, $0.01 \mathrm{M}$ spermidine, $\mathrm{pH} 9$ ), $7 \mathrm{U}$ polynucleotide kinase, and $20-25 \mu \mathrm{Ci}\left[\gamma^{-32} \mathrm{P}\right] \mathrm{ATP}$ $(5000-6000 \mathrm{Ci} / \mathrm{mmol})$. The kinase reaction was run at $37^{\circ} \mathrm{C}$ for $35 \mathrm{~min}$. Approximately $100 \mathrm{mU}$ apyrase $(4 \mu \mathrm{l})$ was added and incubation continued $30 \mathrm{~min}$.

HPLC. A Varian 5060 ternary liquid chromatograph equipped with a UV-100 detector was used. The column was an Ultrasphere ion pair C18 $4.6 \times 250 \mathrm{~mm}$ with a $70-\mathrm{mm}$ guard column of octadecylsilane. UV detection was at $254 \mathrm{~nm}$. For radioactivity deter- 
minations, fractions $(1.5 \mathrm{ml})$ were collected in plastic minivials using a Helirac fraction collector. For tritium-labeled samples, radioactivity was determined using $0.5-\mathrm{ml}$ aliquots of column fractions in $5 \mathrm{ml}$ of Safety-Solve (Research Products International, Elk Grove Village, IL). Radioactivity of ${ }^{32}$ P-labeled samples was determined by Cerenkov counting. An LKB 1218 Rackbeta scintillation spectrometer was used.

Radiolabeled samples or standards were combined with unlabeled adduct standard and injected into the HPLC via a Rheodyne 7125 injector using a 50 - or $100-\mu 1$ loop. Labeled nucleotides from between 1 and $3 \mu \mathrm{g}$ of DNA ( $10 \mu 1$ of a $24-\mu 1$ labeling reaction) were injected in a total volume of $50 \mu \mathrm{l}$. Gradient I had initial conditions of flow $1.5 \mathrm{ml} / \mathrm{min}$, $90 \% 30 \mathrm{mM} \mathrm{KPO}_{4}(\mathrm{pH} \mathrm{6}), 10 \% \mathrm{CH}_{3} \mathrm{CN}$ for 10 min followed by $90 \% 30 \mathrm{~mm} \mathrm{KPO}_{4}(\mathrm{pH} 6)$ containing $5 \mathrm{mM}$ TBAP, $10 \% \mathrm{CH}_{3} \mathrm{CN}$ increasing linearly to $50 \%$ at $50 \mathrm{~min}$. This gradient was used to separate adducted nucleotides from normal nucleotides, $P_{\mathrm{i}}$, and residual ATP. The column was prepared for the next sample by a 10 -min wash at $20 / 80$ phosphate-TBAP: $\mathrm{CH}_{3} \mathrm{CN}$ and reequilibrated at the starting conditions. The loop and syringe used for sample injection were rinsed between uses. There was no evidence of contamination between samples.

\section{RESULTS}

\section{HPLC Separation of Nucleotide Standards}

Gradient I allowed a clean separation of adducted nucleotides from normal nucleotides, $P_{\mathrm{i}}$, and residual ATP. If conditions were modified by having $5 \mathrm{mM}$ TBAP in the eluting buffer from the start (gradient II), all four normal nucleotides as well as ATP and nucleotide-carcinogen adducts could be separated. However, counts of ${ }^{32} \mathrm{P}$, presumably from impurities in the $\left[\gamma-{ }^{32} \mathrm{P}\right] \mathrm{ATP}$, were still eluting from the column when AF adducts began to elute. Thus, gradient I was used to avoid interference in the quantitation of ad- duct levels (Fig. 1). The adduct peak (dG-C8AAF) elutes at $36 \mathrm{~min}$ with gradient I or II (Fig. 1). Use of gradient I results in a lower level of background radioactivity in the vicinity of the adduct (higher signal-to-noise ratio) when using ${ }^{32} \mathrm{P}$-labeled samples.

The choice of ion-pairing agent is crucial to the separation. When tetramethylammonium salt was substituted for tetrabutylammonium, the dG-C8-AAF standard eluted at $21 \mathrm{~min}$ rather than $36 \mathrm{~min}$ (Fig. 2). This earlier elution was unacceptable as nonadduct ${ }^{32} \mathrm{P}$ from the labeling mixture was not adequately eluted from the column before the adduct eluted.

\section{HPLC Separation of ${ }^{3} H$-Labeled Aminofluorene Adducts}

dG-C8-[ $\left.{ }^{3} \mathrm{H}\right] \mathrm{AAF}$ prepared by reacting mouse hepatic DNA with tritium-labeled $N$ acetoxy-AAF at pH 5 eluted as a single major radioactive peak at $37 \mathrm{~min}$ (gradient $\mathrm{I}$ ). This coincided with the uv detection of $\mathrm{dG}-\mathrm{C} 8$ AAF (Fig. 3).

The $3^{\prime}$-monophosphate of dG-C8-AAF eluted 2-3 min earlier than the 3',5'-diphosphate, while the $3^{\prime}$-monophosphate of dGC8-AF eluted at nearly the same position as the diphosphate of the acetylated adduct.

\section{HPLC Detection of 2-AF Adducts Formed in Vivo}

Hepatic DNA from mice exposed to 2-AF was prepared, hydrolyzed, extracted, ${ }^{32} \mathrm{P}$ postlabeled, and analyzed by HPLC. With gradient $\mathrm{I}$, two peaks of ${ }^{32} \mathrm{P}$ were detected: fraction 36 and fractions $40-42$. The uv standard eluted between 36 and $37 \mathrm{~min}$. Fractions 36 and 37 accounted for approximately $20 \%$ and fractions $40-42$ for $80 \%$ of adduct ${ }^{32} \mathrm{P}$ radioactivity.

Control DNA was always run under identical labeling and HPLC conditions. Figure 4A shows the elution profile of a control B6 mouse, whereas Fig. 4B shows the pattern of elution for 2-AF in hepatic DNA from a treated B6 mouse. Figure $4 \mathrm{C}$ shows the 
A.

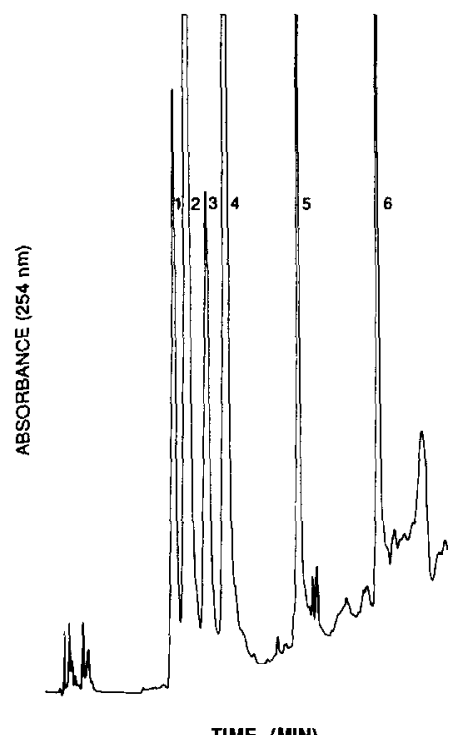

B.

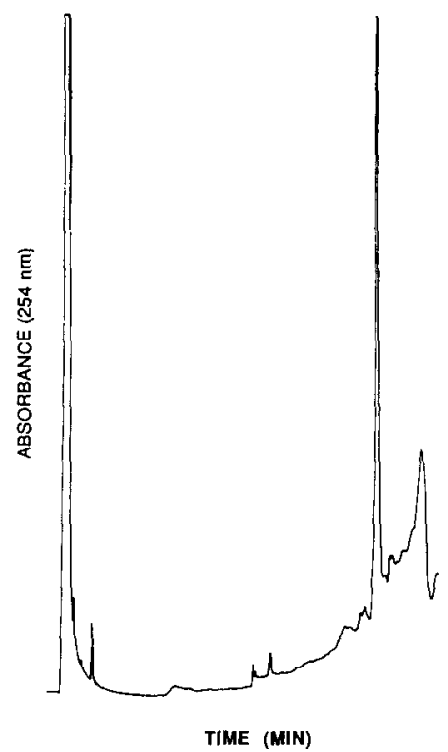

FIG. 1. HPLC separation of $3^{\prime}, 5^{\prime}$-diphosphates of deoxycytidine, deoxyguanosine, thymidine, and deoxyadenosine (1-4), ATP (5), and dG-C8-AAF-3',5'-diphosphate (6). Detection by uv absorbance at $254 \mathrm{~nm}$. (A) Gradient II; retention times were 13.8, 15.2, 17.4, 19.4, 27.4, and 36.1 min. (B) Gradient I; retention time of dG-C8-AAF-3',5'-diphosphate was $35.9 \mathrm{~min}$.

difference between treated and control hepatic DNA for the fractions where adducts elute.
The amount of adduct found is calculated from the radioactivity found in fractions 36 , 37 and $40-42$, the efficiency of counting, the
A.

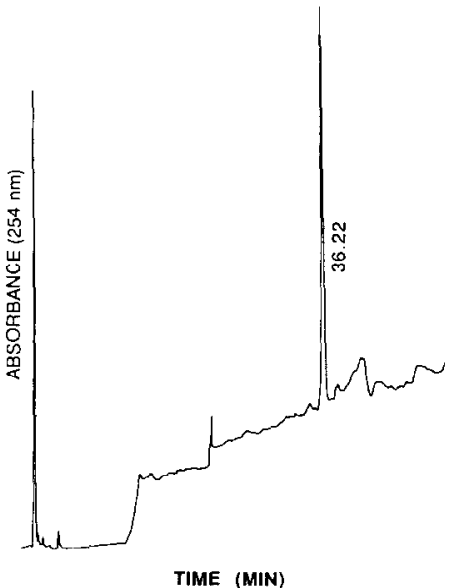

B.

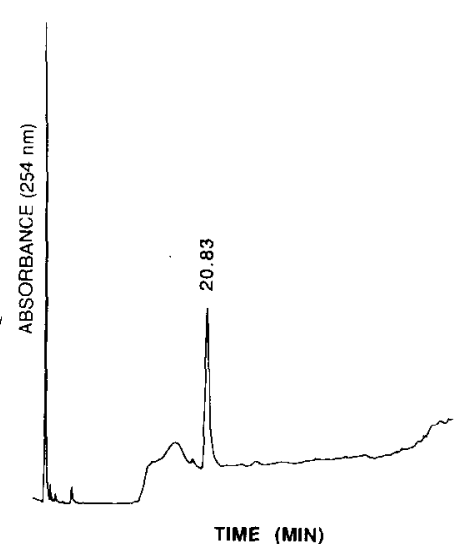

FIG. 2. Effect of chain length of ion-pairing agent on adduct retention time. dG-C8-AAF-3',5'-diphosphate was run using Gradient I. (A) Gradient contained tetrabutylammonium salt. (B) Gradient contained tetramethylammonium salt. 


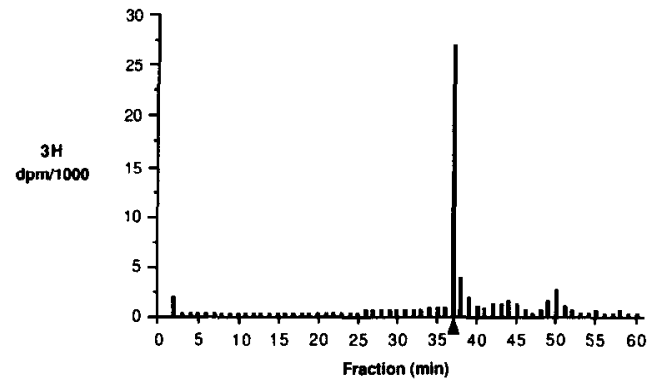

FIG. 3. HPLC profile of dG-C8 ${ }^{3} \mathrm{H}-\mathrm{AAF}-3^{\prime}, 5^{\prime}$-diphosphate ${ }^{3} \mathrm{H}$-labeled adduct standard was prepared from $N$ $\left[{ }^{3} \mathrm{H}\right]$ acetoxy-AAF and mouse hepatic DN $\Lambda$. Adducted DNA was hydrolyzed, phosphorylated with ATP and polynucleotide kinase, and run on HPLC using gradient I. Aliquots of each fraction were added to scintillation cocktail and counted for ${ }^{3} \mathrm{H}$. The arrow in this and subsequent figures shows the retention of the internal standard of dG-C8-AAF-3',5'-diphosphate as detected by its absorbance at $254 \mathrm{~nm}$.

specific activity of the $\left[\gamma^{32} \mathrm{P}\right] \mathrm{ATP}$ used in the labeling, and the sample size of DNA nucleotides analyzed. Results from $11 \mathrm{~B} 6$ and $5 \mathrm{~A}$ mice gave values of $0.327 \pm 0.058$ (SE) pmol adduct/mg DNA for B6 and $0.106 \pm 0.019$ $\mathrm{pmol}$ adduct/mg DNA for A mice. The interstrain difference is statistically significant at $P<0.01$.

\section{HPLC Detection of DNA ${ }^{32}$ P-Postlabeled Adducts of Benzo[a]pyrene, 4- Aminobiphenyl, 2-Naphthylamine, Benzidine, Safrole, and Methyleugenol}

Skin DNA from mice treated with benzo[a]pyrene and hepatic DNA from mice treated with 4-aminobiphenyl, 2-naphthylamine, benzidine, safrole, and methyleugenol were subjected to the HPLC/32P-postlabeling procedure. For each substance, control DNA from a mouse dosed with solvent only was analyzed and radioactivity in the control was subtracted from the ${ }^{32} \mathrm{P}$ found in the treated DNA. In all cases, peaks of ${ }^{32} \mathrm{P}$ radioactivity were found in the region of the chromatogram near where 2-AF adducts eluted.
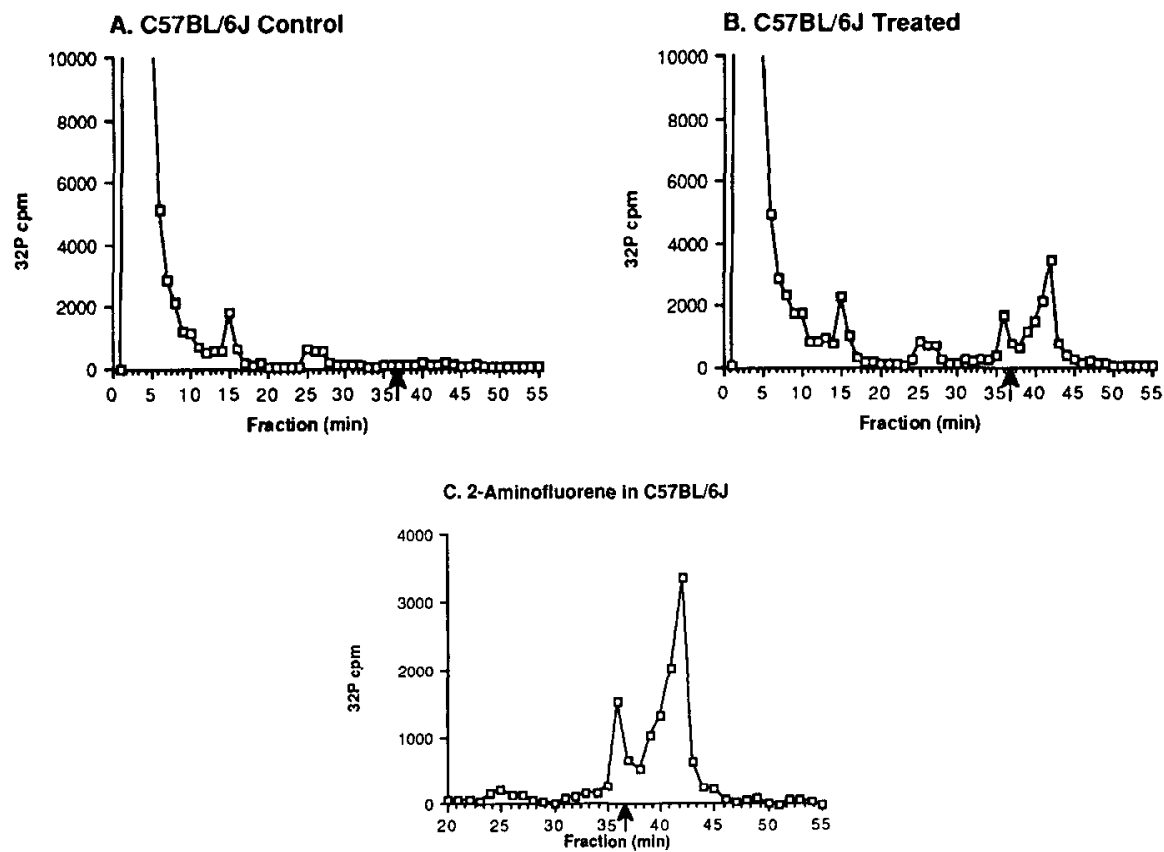

FIG. 4. HPLC analysis of ${ }^{32} \mathrm{P}$-postlabeled C57BL/6J mouse hepatic DNA using gradient I. (A) Controlmouse treated with solvent (dimethyl sulfoxide) only. (B) Treated-mouse after $3 \mathrm{~h}$ exposure to 2-AF. (C) Hepatic DNA from 2-AF-treated mouse less control. For both treated and control DNA, fraction 2 had the greatest radioactivity with approximately $6.2 \times 10^{6} \mathrm{cpm}$. 
The amounts of radioactivity varied considerably from one carcinogen to another partly because of inherent differences in carcinogen binding indices and partly because different amounts of DNA were analyzed, different concentrations and specific activities of $[\gamma$ ${ }^{32}$ P]ATP were used, and probably various nucleotide adducts behave differently in the steps of the method. Examples of chromatograms are shown in Fig. 5. These examples show the qualitative detection of DNA-aromatic carcinogen adducts. Due to variations in the amounts of DNA, carcinogen, and ATP used, no quantitative comparisons should be made from the results shown in Fig. 5.

\section{DISCUSSION}

The method of ${ }^{32} \mathrm{P}$-postlabeling DNA-carcinogen adducts developed by Randerath and Gupta et al. $(1,2)$ is sensitive, fairly rapid, and applicable to adducts of a wide range of aromatic or bulky carcinogens. We have replaced the thin-layer chromatographic separation of ${ }^{32} \mathrm{P}$-labeled adducted nucleotides with high-performance liquid chromatography. Our procedure, like the TLC method of Reddy et al. (3), can be applied to a range of aromatic compounds, some of which are described in this report. Likewise, a complex mixture of potential carcinogens can be analyzed for adduct formation without a detailed knowledge of the chemical identity of the compounds (e.g., coal liquification products, data not shown).

Since the Randerath procedure uses ionexchange thin-layer materials, we originally thought that ion-exchange HPLC would be useful in separating normal and adducted nucleotides. Although normal nucleotides were adequately resolved by ion-exchange HPLC, modified nucleotides were not clearly distinguishable. The affinity of aromatic DNA adducts for reverse-phase chromatography materials (5) suggested that reverse-phase HPLC might give the desired resolution. Reddy $e t$ al. (3) had used reverse-phase TLC as a purifica- tion step in TLC analysis of ${ }^{32} \mathrm{P}$-postlabeled aromatic adducts. To cleanly separate normal from aromatic nucleotides, we modified the reverse-phase ion-pairing HPLC method of Payne and Ames (6) for separation of nucleotides. The gradient elution described in our report elutes normal nucleotides and material from the ATP labeling in a single early peak, washes background ${ }^{32} \mathrm{P}$ from the column, and resolves 2-AF adducts into two separate peaks which presumably correspond to dG-C8-AAF and dG-C8-AF (Fig. 4).

We have been able to identify the peak with a retention time of 36-37 min as $N$-acetyl $-N$ (deoxyguanosin-8-yl)-2-aminofluorene-3',5'diphosphate by use of standards prepared by reacting $\mathrm{N}$-acetoxy-2-acetylaminofluorene with pdGp, or with deoxyguanosine 3'-phosphate followed by phosphorylation at the $5^{\prime}$ position. Standard dG-C8-AAF was also prepared by hydrolysis and phosphorylation of DNA that had been reacted with $N$-acetoxy2-AAF. In vitro incubation of $N-\left[{ }^{3} \mathrm{H}\right]$ acetoxy$A A F$ with isolated DNA gave only a single radioactive peak, coeluting with uv standard of the nucleotide $3^{\prime}, 5^{\prime}$-diphosphate of dG-C8AAF (Fig. 3).

The peak eluting at $40-43$ min contained about $80 \%$ of the total adduct radioactivity. We tentatively identify this later peak as the nonacetylated nucleotide adduct dG-C8-AF. The basis for this assumption is that previous studies have shown the major hepatic DNA adduct formed after 2-AF exposure to be dGC8-AF $(2,7)$. The later eluting peak is found after in vivo exposure to 2-AF but not after in vitro incubation with $N$-acetoxy-2-AAF. This is to be expected from the known pathways of metabolic activation of 2-AF which include formation of $N$-acetoxy-2-aminofluorene by either direct $O$-acetylation or $N, O$-acetyl transfer followed by removal of the acetoxy group to give an electrophilic arylnitrenium ion capable of combining covalently with DNA to give the dG-C8-AF adduct (8). The formation of a labile $N$-acetoxy-2-aminofluorene intermediate occurs only through metabolic activation. Since we found the putative 

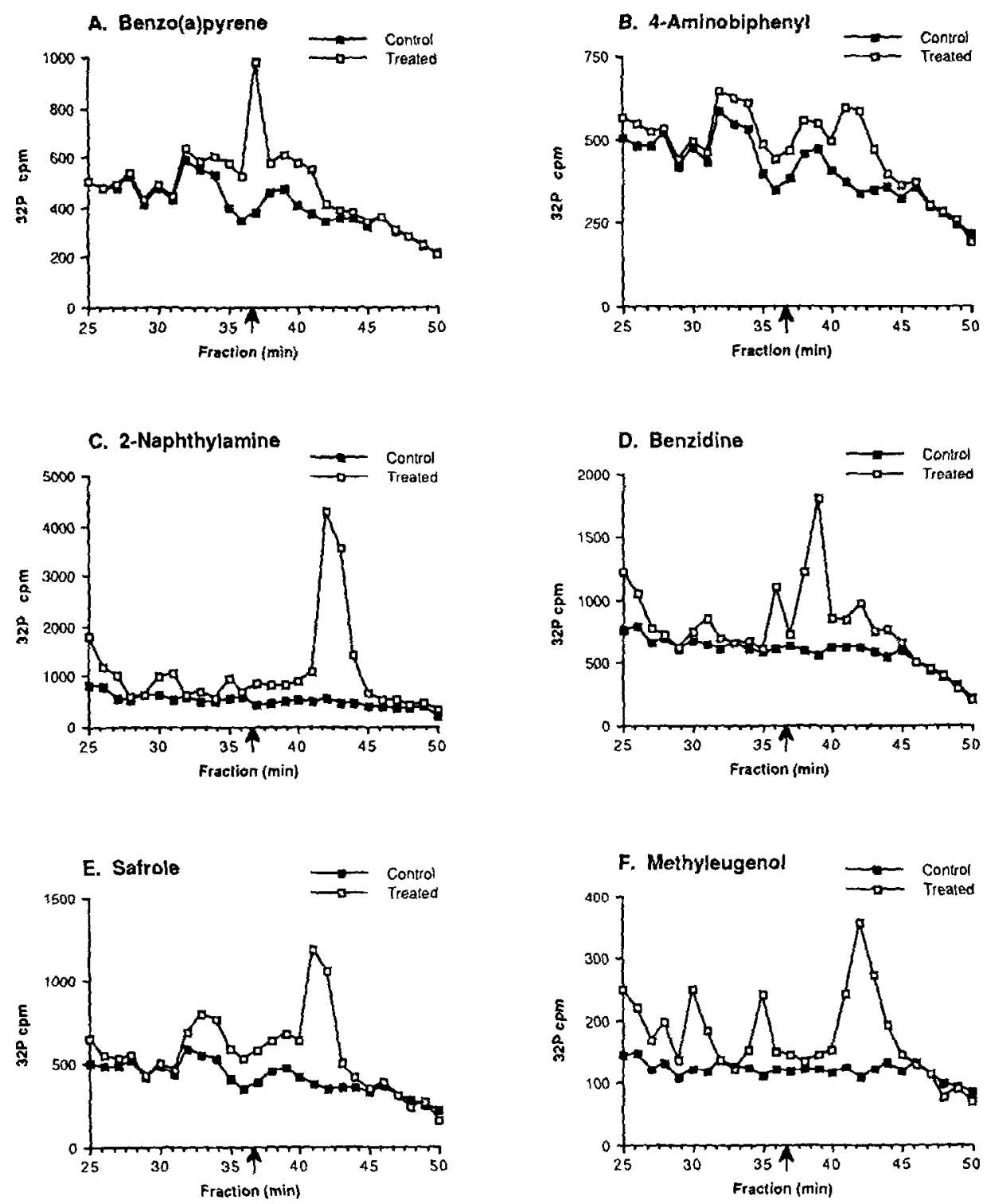

FIG. 5. (A) HPLC analysis of ${ }^{32} \mathrm{P}$-postlabeled skin DNA from benzo[ $a$ ]pyrene-treated mouse and control mouse skin DNA (ATP specific activity $=4500 \mathrm{Ci} / \mathrm{mmol}$ ). (B-F) Each chromatogram shows HPLC analysis of ${ }^{32} \mathrm{P}$-postlabeled hepatic DNA of treated mouse and the matching control. (B) 4-ABP (ATP specific activity $=4500 \mathrm{Ci} / \mathrm{mmol}$ ). (C) $2-\mathrm{NA}$ (ATP specific activity $=5500 \mathrm{Ci} / \mathrm{mmol}$ ). (D) Benzidine (ATP specific activity $=4500 \mathrm{Ci} / \mathrm{mmol}$ ). (E) Safrole (ATP specific activity $=4500 \mathrm{Ci} / \mathrm{mmol}$ ). (F) Methyleugenol (ATP specific activity $=1750 \mathrm{Ci} / \mathrm{mmol}$ ).

dG-C8-AF adduct only following in vivo experiments and under conditions known to produce mainly dG-C8-AF, we provisionally identify the adduct peak at $40-43 \mathrm{~min}$ as $\mathrm{dG}$ C8-AF. Furthermore, the increase in reten- tion time of the second 2-AF nucleotide $3^{\prime}, 5^{\prime}-$ diphosphate adduct peak (3-5 min) compared to the acetylated nucleotide adduct is the same increase seen between standards of nucleosides of dG-C8-AAF and dG-C8-AF 
when run on gradient I (data not shown). Definitive identification of the second adduct peak awaits synthesis of the proper standard.

The reverse-phase ion-pair HPLC separation appears to depend on the affinity of the aromatic moiety of the adduct for the $\mathrm{C} 18$ reverse-phase column material. Thus, the adducts are bound to the column matrix while normal nucleotides and other charged molecules are removed. In the presence of the ionpairing agent (added after $10 \mathrm{~min}$ in gradient I) the aromatic adduct-nucleotide-tributylammonium complex is eluted by increasing concentrations of acetonitrile. Since several diverse adducts elute at a fairly similar acetonitrile concentration, the structure of the carcinogen is not the only determinant of elution position. The evidence suggests that the number of phosphates and thereby the number of tetrabutylammonium groups play a significant part in determining the elution position of adducts (e.g., the earlier elution of $3^{\prime}$ monophosphate compared to $3^{\prime}, 5^{\prime}$-diphosphate of dG-C8-AAF). The importance of the chain length of the ion-pairing agent is demonstrated by the dramatic decrease in retention of dG-C8-AAF-3',5'-diphosphate when tetramethylammonium is substituted for tetrabutylammonium (Fig. 2). The finding of a second, later cluting peak of ${ }^{32} \mathrm{P}$-labeled adduct (presumably C8-dG-AF) when DNA is modified in vivo by $2-\mathrm{AF}$ but not when $N$-acetoxy-AAF is reacted with DNA in vitro (compare Fig. 4 with Fig. 3 ) suggests that an acetyl group can influence the retention of adducts on the column.

Two additional comments on the ${ }^{32} \mathrm{P}$-postlabeling method are worthy of mention. A sample of control DNA from an animal of identical genetic and environmental background should be run parallel to that for the carcinogen-treated animal. This is because ${ }^{32} \mathrm{P}$ spots (I-spots) have been found in untreated DNA from various tissues (9). The origin of these spots has been ascribed to environmental factors such as diet or to endogenous DNA-reactive metabolites. The amount and intensity of I-spots appears to increase with the age of the animal. Control hepatic DNA run in the HPLC/ $/{ }^{32} \mathrm{P}$-postlabeling method shows ${ }^{32} \mathrm{P}$ in the area of the chromatogram where adducted nucleotides elute. Although such radioactivity is significantly less than that found in the carcinogen-treated DNA, it can be confusing when working with low adduct levels or unknown compounds. Any attempts to quantitate adducts must take the radioactive background into account.

The second comment deals with the use of butanol extraction to enrich modified nucleotides relative to normal nucleotides. Since the great majority of nucleotides in treated DNA are not modified and adducted nucleotides account for only a small fraction of a percent of the total nucleotides available for labeling, either very large amounts of ${ }^{32} \mathrm{P}$ must be used in labeling or some method is needed to reduce the amount of normal nucleotides available for labeling. Our procedure uses extraction of modified nucleotides into butanol at low $\mathrm{pH}$ and in the presence of a tetrabutylammonium phase transfer reagent as described by Gupta (4). A different method involving nuclease P1 digestion of normal nucleotides has been described by Reddy and Randerath (10). In theory this method hydrolyzes the 3'-phosphate from nucleotides, converting them to nucleosides which are no longer substrates for polynucleotide kinase. The adducted nucleotides are supposed to be resistant to this hydrolysis and can then be phosphorylated to the ${ }^{32} \mathrm{P}$ labeled $3^{\prime}, 5^{\prime}$-diphosphates. Since we were not successful in using this procedure with 2-AF adducts, we did not pursue its applicability to other carcinogen adducts.

Another approach to solving the problem of minute amounts of DNA-carcinogen adducts in the presence of larger amounts of normal nucleotides is used by Randerath et al. (11). According to this method, with limiting amounts of $\left[\gamma-{ }^{32} \mathrm{P}\right] \mathrm{ATP}$, adducted nucleotides are labeled preferentially to normal nucleotides, achieving "adduct intensification." The intensification is variable and 
must be determined for each adduct by using the postlabeling under "normal" conditions, i.e., excess $\left[\gamma_{-}{ }^{32} \mathrm{P}\right] \mathrm{ATP}$, and again under "intensification" conditions, i.e., $\left[\gamma-{ }^{32} P\right]$ ATP being the limiting reagent.

HPLC analysis of ${ }^{32} \mathrm{P}$-postlabeled hepatic DNA from mice treated with 2-AF revcaled two areas of radioactivity (Fig. 4). The area eluting in fractions 36,37 and corresponding to dG-C8-AAF accounted for $18 \%$ of the adduct radioactivity. The second area in fractions $40-42$ represented the remaining $82 \%$ of adduct radioactivity. This distribution is very similar to the distribution reported for adducts in rat liver DNA of $15 \% \mathrm{dG}-\mathrm{C} 8-\mathrm{AAF}$ and $80 \%$ dG-C $8-A F(8)$.

Experiments comparing adduct formation in rapid and slow acetylator mice showed a threefold higher adduct load in hepatic DNA of rapid acetylators $3 \mathrm{~h}$ after exposure to 2$\mathrm{AF}$. The direction and magnitude of the difference between $\mathrm{B} 6$ and A mice are very similar to those found for in vitro liver arylamine $N$-acetyltransferase activity (12), 2-AF $\mathrm{N}$-acetylation rates in primary hepatocyte cultures (13), and 2-AF elimination rates for intact mice (14). There is, therefore, a strong suggestion that rapid acetylator mice metabolize 2-AF more rapidly than slow acetylators and that among the metabolites formed are compounds that bind to hepatic DNA.

The accuracy of quantitation of adducts by ${ }^{32} \mathrm{P}$ postlabeling depends on the efficiencies of several steps in the protocol. Incomplete hydrolysis of purified DNA, incomplete extraction of adducts into butanol, and less than $100 \%$ reaction in the polynucleotide kinase step can result in a value for adduct formation lower than the actual value. We have examined this problem using ${ }^{3} \mathrm{H}$-labeled aminofluorene and benzo $[a]$ pyrene adducts. For both compounds we compared the level of adducts determined by the ${ }^{32} \mathrm{P}$-postlabeling method with the level determined using ${ }^{3} \mathrm{H}$ labeled carcinogen and hydrolyzing, extracting, and phosphorylating as for unlabeled carcinogen except using nonradioactive ATP. The results indicated that the ${ }^{32} \mathrm{P}$ value was 50 to $60 \%$ of the adducts determined by the tritium content of adducted DNA. Furthermore, we found that most of the losses occur in the butanol extraction step. Although Gupta (4) reports 79 to $99 \%$ efficiency for butanol extraction of aminofluorene adducts formed by reaction of ultimate carcinogens with DNA in vitro, we have not been able to duplicate such high values. The loss of adducts in the three steps mentioned above would be expected to occur whether the analysis was carried out by HPLC or TLC. In TLC analysis additional losses may occur in cutting or scraping the TLC plates to recover adduct spots for counting.

The adduct amounts we report have not been corrected for efficiency of extraction. In a comparison of adduct formation between strains or between tissues using the same carcinogen, the efficiency of extraction is assumed to be almost constant. Thus, B6 mice accumulate three times the hepatic DNA adducts of A mice whether one corrects for efficiency or not. Additional methods to improve the enrichment of adducts before postlabeling are under study.

Although no general relationship between adduct structure and HPLC retention time is known at this time (other than the special situation of the effect of an acetyl group on a particular adduct described above), a comparison of the adduct peaks found by HPLC to adducts found by other methods is interesting and informative.

Previously Lu et al. (15) used ${ }^{32} \mathrm{P}$ postlabeling and TLC to examine adduct formation in mouse liver DNA after exposure to benzo[a]pyrene and 4-aminobiphenyl. Two major benzo $[a]$ pyrene adducts were detected, accounting for approximately 55 and $25 \%$ of adduct radioactivity. The radioactivity in the two benzo $[a]$ pyrene adduct peaks detected by HPLC represents 67 and 33\% of adduct radioactivity (Fig. 5A).

For 4-aminobiphenyl, Lu et al. (15) found one major radioactive spot formed from mouse liver. Our results show a single peak preceded by a low plateau of radioactivity 
(Fig. 5B). The nonacetylated dG-C8-ABP adduct has been reported to account for at least $80 \%$ of ABP adducts in rat liver (16).

Our results for 2-naphthylamine show a single adduct peak eluting at 42-43 $\mathrm{min}$ (Fig. $5 \mathrm{C})$. This position corresponds to the major adducts seen with 2-AF and 4-ABP. 2-NA has been reported to produce a dG-C8-2-NA adduct with dog liver DNA and dog urothelial DNA, as well as an $N$-2-dG and an $N$-6-deoxyadenosinyl adduct (17). Information on mouse hepatic DNA or adducts detected by ${ }^{32} \mathrm{P}$ postlabeling is lacking for 2-NA.

Benzidinc has been reported to produce only a single adduct with mouse hepatic DNA, $N$-(deoxyguanosin-8-yl)- $N$-acetylbenzidine, one day after 7 days of oral administration (18). Reddy et al. (3) reported one major and two minor adducts from mouse skin DNA with benzidine. Our results show a major adduct and two or three minor peaks of radioactivity with mouse hepatic DNA (Fig. 5D). The discrepancy between our results and those of Martin et al. (18) may be due to the increased sensitivity of ${ }^{32} \mathrm{P}$ methods such as ours and that of Reddy et al. (3) compared to the use of ${ }^{3} \mathrm{H}$ labeled carcinogen by Martin et al. (18). Another possibility is suggested by the work of Kennelly et al. (19), who found at least one additional benzidine adduct in rat hepatic DNA treated in vitro. It was suggested that the additional adduct was not found in earlier experiments done in vivo because of the action of repair systems. Similarly one could speculate that in the 3 -h exposure used here, repair mechanisms were not fully functional and additional adducts were found. Studies of adduct persistence would address this question.

The alkenylbenzenes safrole and methyleugenol have been examined using ${ }^{32} \mathrm{P}$ postlabeling by Lu $e t$ al. (15) and Randerath $e t$ al. (20). Lu found two major hepatic DNA adducts with safrole which were identified as $\mathrm{dG}$ adducts. The two adducts accounted for 75 and $23 \%$ of adduct radioactivity. Our results with safrole (Fig. 5E) show a single peak of radioactivity preceded by a low plateau of radioactivity. With methyleugenol, Randerath obtained an adduct map similar to that of safrole, with $87 \%$ of the radioactivity in a single spot. Our results with methyleugenol (Fig. $5 \mathrm{~F}$ ) show a major adduct with one or two smaller earlier eluting peaks of radioactivity.

The results of analysis of ${ }^{32} \mathrm{P}$-postlabeled DNA-aromatic carcinogen adducts obtained by us using HPLC and TLC results in the literature, as discussed above, are, in general, similar. In some cases differences between the results reported here and results from other laboratories can probably be traced to differences in dosage, method of administration, species or strain of animal, and length of exposure to the carcinogen. Some of the differences in detail are also likely due to differences in the type of separation used: ion exchange for TLC and reverse phase for HPLC. Also, the HPLC method is separating larger molecules than the TLC method in that for HPLC the covalent dG-carcinogen adduct also contains tetrabutylammonium ions bound to phosphates.

While the TLC method often produces more areas of radioactivity on the chromatogram which may indicate resolution of minor adducts, the HPLC method is more rapid and less tedious to perform. As a rapid screening method to detect adduct formation, the HPLC procedure has been shown to be effective in detecting adducts formed by a variety of aromatic carcinogens. We have also shown the value of HPLC analysis in determining formation of specific adducts and the usefulness of the method in measuring differences in DNA damage caused by genetically determined variations in metabolic pathways.

\section{ACKNOWLEDGMENT}

We thank Dr. Michael J. Brabec for his thoughtful suggestions in the early phases of this work.

\section{REFERENCES}

1. Randerath, K., Reddy, M. V., and Gupta, R. C. (1981) Proc. Natl. Acad. Sci. USA 78, 6126-6129.

2. Gupta, R. C., Reddy, M. V., and Randerath, K. (1982) Carcinogenesis (London) 3, 1081-1092. 
3. Reddy, M. V., Gupta, R. C., Randerath, E., and Randerath, K. (1984) Carcinogenesis (London) 5, 231-243.

4. Gupta, R. C. (1985) Cancer Res. 45, 5656-5662.

5. Jeffrey, A. M., Blobstein, S. H., Weinstein, I. B., and Harvey, R. G. (1976) Anal. Biochem. 73, 378385.

6. Payne, S. M., and Ames, B. N. (1982) Anal. Biochem. 123, 151-161.

7. Kriek, E., and Westra, J. G. (1980) Carcinogenesis (London) 1, 459-468.

8. Neumann, H-G. (1986) J. Cancer Res. Clin. Oncol. 112, 100-106.

9. Randerath, K., Reddy, M. V., and Disher, R. M. (1986) Carcinogenesis (London) 7, 1615-1617.

10. Reddy, M. V., and Randerath, K. (1986) Carcinogenesis (London) 7, 1543-1551.

11. Randerath, E., Agrawal, H. P., Weaver, J. A., BordeIon, C. B., and Randerath, K. (1985) Carcinogenesis (London) 6, 1117-1126.
12. Mattano, S. S., and Weber, W. W. (1987) Carcinogenesis (London) 8, 133-137.

13. Hultin, T. A. (1983) Doctoral dissertation, University of Michigan, Ann Arbor.

14. Hultin, T. A., and Weber, W. W. (1985) Drug Metab. Disp. 13, 148-150.

15. Lu, L-J. W., Disher, R. M., Reddy, M. V., and Randerath, K. (1986) Cancer Res. 46, 3046-3054.

16. Gupta, R. C., and Dighe, N. R. (1984) Carcinogenesis (London) 5, 343-349.

17. Beland F. A., and Kadlubar, F. F. (1985) Environ. Health Perspect. 62, 19-30.

18. Martin, C. N., Beland, F. A., Roth, R. W., and Kadlubar, F. F. (1982) Cancer Res. 42, 2678-2686.

19. Kennelly, J. C., Beland, F. A., Kadlubar, F. F., and Martin, C. N. (1984) Carcinogenesis (London) 5 , 407-412.

20. Randerath, K., Haglund, R. E., Phillips, D. H., and Reddy, M. V. (1984) Carcinogenesis (London) $\mathbf{5}$, 1613-1622. 